\title{
Percevied Benefits and Issues of Student Learning in Business Case Competition Comparison Study of Serbia, Australia and Thailand
}

\author{
By Vesna Damnjanović* \\ Bill Proud \\ Nopporn Ruangwanit
}

The main aims of this research paper are to identify, compare and contrast different perspectives of students from Serbia, Australia and Thailand regarding their perception of the case learning method. This research study investigates the student benefits, problems and most difficult tasks in defining marketing strategy at business undergraduate case competitions where students from the University of Belgrade, QUT and Thammasat University compete. The quantitative survey methodology has been applied in three different countries and all respondents were students who competed at undergraduate business case competitions all around the world. We used descriptive statistics for presenting results in the study. The findings have identified that the main benefits for using case learning for students in all countries are: learning experience, personal and professional improvement, improving managerial skills and being more attractive in the job market. Furthermore, the negative aspects of case learning have been explored. This research should provide a better direction for professors and students, which could help them with improving the learning process with case studies in the field of marketing.

Keywords: Australia, case competition, Serbia, student benefits, Thailand

\section{Introduction}

Authors define case studies as "a description of a real event, which includes a decision, a challenge, an opportunity, a problem or an attitude with which a person or people in an organization face" (Erskine, Leenders, \& Mauffette-Leender, 1998). A business case imitates a real situation. The unit of analysis in cases varies enormously, from a single individual or an organization, to an entire nation. Cases can range from one page to fifty or more. Case methods are designed to develop and prepare students in many relevant skills. Case methods are intended to develop the student's ability to solve problems using knowledge, concepts, and relevant skills. It focuses on "big" issues and on problem-solving and creativity, rather than simply memorizing facts and details. There was a strong focus on students developing problem-solving skills, critical-reasoning, analytical skills and collaborative

\footnotetext{
* Associate Professor, University of Belgrade, Serbia.

${ }^{\dagger}$ Director of Studies, QUT Business School, Queensland University of Technology, Australia.

*Director, IBMP Program, Thammasat Business School, Thammasat University, Thailand.
} 
skills which they could apply in the workplace, thus making them better employees (Jerrard, 2005). The case method contributes to leadership development. Students learn how to formulate readings and to discriminate among them and learn how to frame and resolve business issues in accordance with the prevailing values (Greenhalgh, 2007). In order to solve a case study, students have to use their logical reasoning skills in some phases, and their intuitive and creative skills (Kreber, 2001). Case teaching and learning has evolved in Business Schools over the last 50-60 years and is now a sophisticated method seen in teaching business skills. Case teaching is an underused, but very effective way of teaching in a number of contexts, and especially in the business situation. Case teaching is unevenly applied. A number of Business Schools such as Harvard, Ivey, IESE, Stanford and Wharton along with some others use cases as their primary teaching method, while most use it occasionally (Byrne, 2012).

Business colleges and universities may be failing to prepare students adequately for their future career. It is becoming important that higher institutions and academia align better with the needs of business and the work environment (Burke \& Rau, 2010). In traditional learning classrooms, professors are responsible for delivering the course materials and monitoring students' performance and assignments. Students play a passive role and are usually not motivated to learn (Umble et al., 2008). Recent research studies (MondéjarJiménez et al., 2010; Byrne, 2012) suggest shifting some of the responsibility to the students. The use of the case study method as an active learning approach allows to the students a better engagement in the learning process. Case competition is one specific and seemingly growing form of case basedlearning. (Gamble, 2014) Case study method can be observed in case competitions as an additional student extra-curricular activity.

Previous research studies also agree that the use of case competitions is more effective than case analysis in the classroom because the students are provided with real feedback for their analyses and recommendations from the company's side. Having top-level management and the CEO of the case company who will evaluate the solutions creates a real-world situation for students. (Corner et al., 2006; Mena, 2010). Case competitions provide an opportunity to make business education meaningful to business students, while providing students with an opportunity to prepare for their upcoming career challenges. Competitions enable students to deal with the challenges of delivering results under pressure, when given an enigmatic real-world business problem. (Bale, Senteza, \& White, 2013). Also, Credle (2007) emphasized that case competitions force students to link information from various data sources and provide supportable assumptions that lead to feasible business decisions.

However in reviewing the data from the case study competitions in the USA and Canada, the improvement of students' practical knowledge and managerial skills (Orlitzky \& Benjamin, 2003; Gamble \& Jelley, 2014), being more attractive on the job market (Burke et. al., 2013) and enhancing team performance (Umble, Umble, \& Artz, 2008; Sachau \& Nass, 2010) are recognized as the main benefits for students. Case competitions in South 
Eastern Europe - Serbia and Croatia (Damnjanovic \& Dlacic, 2015) showed that skills that students developed the most through case study competitions are: teamwork skills, problem solving, analytical and argumentation skills and how to perform market research. (Dlačić, Damnjanović, \& Ribarić, 2017). There is limited literature on the research studies that provide more information about students' benefits and issues at international case competitions in Thailand and Australia.

The aim of this research study is to understand the student learning benefits and issues in various international business undergraduate case competitions. This study emphasizes the perspective of students' from leading universities (Queensland University of Technology, Thammasat University and University of Belgrade) that compete at global case competitions around the world. The existing literature is limited and mainly comprises of best practices in the active case learning field, and is a comparison of similarities and differences of student attitudes and experiences among three different countries located in different regions all around the world: Australia is a country comprising the mainland of the Australian continent, Thailand from Southeast Asia and Serbia from Southeast Europe.

The rest of the paper is structured as follows. First, an overview of case competitions is provided followed by the explanation of the methodology used in the research. Then the findings and the discussion part follows. The paper ends with the conclusion, pointing out the limitations and possibilities for further research.

\section{Business Undergraduate International Case Competitions}

The success of case teaching and learning in the United States has spread around the world and developed a competitive environment. The case competition concept was originally developed in the United States and only included domestic universities. The notion of expanding to include international competitions emerged later, with the concept eventually taking hold across North America, Western Europe, and Europe generally, Asia, particularly South East Asia, Australia and competitions in all parts of Canada.

The focus of this paper is explaining international business case competitions for undergraduates. Before explaining data collected and main findings from research, we will briefly explain the structure and process of the business international case competition for undergraduate students. Each school provides a team of four students from a Faculty of Business who specializes in a different background: marketing, finance, accounting, economics, information technology, engineering and international business. Each team consists of students and a case advisor: university staff or a person from practice. The role of the case advisor is to select the team, create the student team and prepare them for case competitions. The team is invited by the Host University. These case competitions are invitation only usually based on results from previous years. Each team needs to make a case solution Power Point presentation in 
front of a jury consisting of people from the industry sector (top management level and consultants). The process of the case analysis and presentation consists of: students are given a case or cases that they had not seen before and are sequestered in a room for limited hours. A Jury panel evaluates team solutions for 20 minutes and the panel would have 15 minutes in total to ask questions. Jury panel evaluate: content, presentation skills and a question and answer part. All presentations are presented in the English language. Participants in all of the varying formats exercise skills and knowledge on a real world case from an actual organization, with support corporate representatives who can provide some facts and insights and possibly limited professional advice. Each case competition chooses the top three winning universities and the number of schools who participated varies from 12 to 20 schools. The Auckland University has compiled a list of results from past undergraduate international case competitions with an invitation only from 2011 to 2016. This list contains information on the host, winner of the competition, as well as the universities that came second and third (or made it to the final). Statistics show that the number of global case competitions that are being organized yearly has increased from 13 in 2011 to 22 in 2016 (University of Auckland undergraduate international case competition list, see Appendix 1.). We will explain more about case competitions in Thailand, Serbia and Australia.

Thammasat Undergraduate Business Challenge (TUBC) is an international business case competition for undergraduates from 16 leading international business schools hosted by the Thammasat Business School in Thailand. TUBC 2016 will mark the $19^{\text {th }}$ year of continuing success in the global business arena; considering the Asia's longest running business case competition. Each team needs to solve one long case about the Thai market (TUBC, n.d.).

Belgrade Business International Case Competition (BBICC) is an international undergraduate case competition organized by the Faculty of Organizational Sciences of the University of Belgrade since 2013 in South Eastern Europe (BBICC, n.d.). This competition consists of 16 leading business schools from all around the world (U.S.A., Canada, Europe, Australia and Oceania, Asia) solving short and long business cases from Serbia.

AUBCC is an annual international case competition that brings together 16 undergraduate university students teams from across the world to compete in fast-paced and challenging business case studies in Australia. The AUBCC is a joint initiative of the University of Melbourne, Faculty of Business and Economics, the University of New South Wales Australian School of Business and the Queensland University of Technology Business School. The first competition was held in Brisbane in 2014, the second in Sydney in 2015 and the third edition will be held in Melbourne in December 2016. Each team needed to solve three cases: two short and one long case (AUBCC, n.d.). 


\section{Methodology}

\section{Research Questions}

The proposed research questions (RQs) of this research paper can be framed as following:

RQ1: How do students who compete at business undergraduate case competitions, perceive benefits, issues and most difficult tasks in the marketing field in international case competitions?

RQ2: What are the differences and similarities between Serbian, Australian and Thai students in relation to the benefits and issues in business case study competitions?

\section{Study Design}

In order to explore the proposed research question, an on-line quantitative survey was undertaken in February - April 2016 with a range of students who attend global business undergraduate case competitions from leading universities. A questionnaire was created based on previous studies about case study competition (Damnjanovic \& Dlačić, 2015). All viewpoints and characteristics used in the research analysis were evaluated based on 5-point Likert scales. Hence, perceived benefits of case study analysis were anchored at 1, unimportant, and at 5, extremely important. Issues in the case study analysis as well as difficult tasks in marketing in case study analysis was anchored at 1, unimportant, and 5, important.

\section{Sample Characteristics}

In the research study, we had 197 students participating at business global case competitions all around the world. As we mentioned before, these global competitions are invitation only. Sample characteristics are as follows: $47.7 \%$ of the respondents are female, and $55.2 \%$ are of age 18 to 26 , most of the respondents are of age 21 (17.9\%), $23(16.4 \%)$ and $22(13.3 \%)$. The respondents most common majors are: Marketing 28.9\%, Sales 1.5\%, Information technology 5.6\%, Accounting 15.7\%, Finance 28.9\%, Business Law 4.1\%, International Business $7.1 \%$, Management $15.2 \%$, Economics $8.6 \%$ and Engineering $1.5 \%$. Our sample covered the following four continents: Europe 21.8\%, Asia 26.9\%, North America 16.7\%, Australia and Oceania 34.5\%. All of the respondents are from leading universities. The main focus of our research is to identify the similarities and differences between Australia, Thailand and Serbia. Respondents from Thailand are from Thammasat University and Chulalongkorn University (14.7\%). Respondents from Australia are from The Queensland University of Technology, The UNSW Australia Business School and The University of Melbourne (24.9\%). Respondents from Serbia are from The University of 
Belgrade (12.2\%). Respondents from other countries are from Norway, Denmark, Portugal, Hong Kong, Singapore, Canada, USA and New Zealand. In the research study they will be named as "Others". For detailed results and sample characteristics see table 1 .

Table 1. Sample Characteristics

\begin{tabular}{|l|c|c|}
\hline Country & University name & Percentage \\
\hline Norway & BI Norwegian Business School & 2.5 \\
\hline Denmark & Copenhagen Business School & 4.6 \\
\hline Portugal & University of Porto & 2.5 \\
\hline Serbia & University of Belgrade & 12.2 \\
\hline Thailand & Chulalongkorn University & 3.0 \\
\hline Thailand & Thammasat University & 11.7 \\
\hline Hong Kong & Hong Kong University & 0.5 \\
\hline Hong Kong & Hong Kong University of Science and & 1.0 \\
& Technology & 0.5 \\
\hline Singapore & Nanyang Technological University & 5.1 \\
\hline Singapore & National University Of Singapore & 5.1 \\
\hline Singapore & Singapore Management University & 6.6 \\
\hline Canada & Concordia University & 1.5 \\
\hline Canada & McGill University & 4.1 \\
\hline Canada & Simon Fraser University & 0.5 \\
\hline USA & University of Berkeley & 1.0 \\
\hline USA & University Of Florida & 1.0 \\
\hline USA & University of Southern California & 2.0 \\
\hline USA & Wharton School Of The University Of & 18.8 \\
\hline Australia & Pennsylvania & 5.1 \\
\hline Australia & Queensland University of Technology & 1.0 \\
\hline Australia & The UNSW Australia Business School & 3.0 \\
\hline New Zealand & University of Melbourne & 6.6 \\
\hline New Zealand & University of Auckland & \\
\hline & University of Otago & \\
\hline
\end{tabular}

Several statistical methods belonging to descriptive statistics were used in the data analysis. The obtained data were analysed using SPSS 22.0 statistical software. Also, a qualitative analysis was applied in assessing students' perceptions of the case study learning process.

\section{Findings and Discussion}

A data analysis was performed to identify the benefits that students perceive as most important when the case study method is applied in global business case competitions. The research results are presented in Table 2. 
Table 2. Perceived Benefits of Case Study Competitions

\begin{tabular}{|l|c|c|}
\hline \multicolumn{1}{|c|}{ Benefit } & Mean & $\begin{array}{c}\text { Std. } \\
\text { deviation }\end{array}$ \\
\hline Personal improvement & 4.73 & 0.509 \\
\hline Development of presentation skills & 4.7 & 0.552 \\
\hline Professional improvement & 4.68 & 0.55 \\
\hline Work under pressure skills & 4.67 & 0.56 \\
\hline $\begin{array}{l}\text { Problem solving skills and analytical skills are being } \\
\text { developed }\end{array}$ & 4.65 & 0.584 \\
\hline Gaining new knowledge & 4.47 & 0.746 \\
\hline Development of teamwork skills & 4.47 & 0.689 \\
\hline Development of time management skills & 4.39 & 0.765 \\
\hline Meeting new people from different countries & 4.35 & 0.771 \\
\hline $\begin{array}{l}\text { Mentor's feedback after case study simulations when } \\
\text { preparing for case competitions }\end{array}$ & 4.35 & 0,764 \\
\hline Gaining knowledge about different markets & 4.29 & 0.772 \\
\hline Development of leadership skills & 4.27 & 0.804 \\
\hline $\begin{array}{l}\text { Students learning from each other - exchange of } \\
\text { ideas and thoughts while cracking the case study }\end{array}$ & 4.22 & 0.802 \\
\hline Travelling to other countries & 4.19 & 0.926 \\
\hline Easy adaptation to other work activities & 4.16 & 0.839 \\
\hline $\begin{array}{l}\text { Feedback 360 - consulting other team members, } \\
\text { suggesting areas of improvement }\end{array}$ & 4.14 & 0.869 \\
\hline Possibility to get a job easier & 4.04 & 0.981 \\
\hline
\end{tabular}

Based on the respondents' answers, the most important benefits that are gained during participation in case study competitions are: personal improvement $(\bar{x}=4.73)$, development of presentation skills $(\bar{x}=4.70)$, the professional improvement $(\bar{x}=4.68)$ and work under pressure skills $(\bar{x}=4.67)$. The characteristics that students perceived to be the least beneficial were possibility to get an internship easier $(\bar{x}=3.84)$ and working with mentors $(\bar{x}=3.98)$. Small standard deviation indicates a small amount of variation in the group that is being studied. When it comes to the personal improvement, standard deviation has the lowest value. This indicates that there are no extremely low results in the data set. On the other hand, possibility to get a job easier has a slightly larger standard deviation mean which indicates that some of the students perceive this benefit as very important, while others do not perceive it as beneficial.

Students' perceived issues in case study competitions were also explored. Research results are presented in Table 3. 
Table 3. Issues in Global Case Study Competitions

\begin{tabular}{|l|c|c|}
\hline \multicolumn{1}{|c|}{ Issue } & Mean & $\begin{array}{c}\text { Std. } \\
\text { deviation }\end{array}$ \\
\hline Time management constraint for solving cases & 3.83 & 0,952 \\
\hline $\begin{array}{l}\text { Insufficient knowledge of local market (relevant for case } \\
\text { study) }\end{array}$ & 3.82 & 0,967 \\
\hline $\begin{array}{l}\text { Filtering the most important information while reading } \\
\text { the case study and making priorities }\end{array}$ & 3.75 & 1,042 \\
\hline $\begin{array}{l}\text { Case study is written badly (without key information, } \\
\text { tables, graphs, pictures) }\end{array}$ & 3.44 & 1,17 \\
\hline Bad teamwork ethics & 3.29 & 1,288 \\
\hline $\begin{array}{l}\text { Case study does not have clearly defined task that is } \\
\text { expected to be solved }\end{array}$ & 3.26 & 1.157 \\
\hline Case study is too long (over 30 pages) & 3.14 & 1.132 \\
\hline Subject of case study is uninteresting] & 2.71 & 1.136 \\
\hline
\end{tabular}

As all the characteristics are issues identified by students as being important and representing obstacles to effective case study analyses in case competitions, the highest grade basically represents the worst characteristic. Students have pointed out what the main problems that might occur while solving the case study at competitions are. These issues in case study competitions that need to be resolved include that the Subject of case study is uninteresting $(\bar{x}=2.71)$, the Case study is too long (over 30 pages) $(\bar{x}=3.14)$ and the Case study does not have a clearly defined task that is expected to be solved $(\bar{x}=3.26)$. The worst characteristics were identified as time management constrain for solving cases $(\bar{x}=3.83)$, Insufficient knowledge of local market (relevant for case study) $(\bar{x}=3.82)$ and filtering the most important information while reading the case study and making priorities $(\bar{x}=3.75)$. Time management constraint for solving cases has the smallest standard deviation. This indicates a small amount of variation in the data set. On the other hand, Bad teamwork ethics has the largest standard deviation mean of all the observed criteria which indicates that some of the students perceive this as a serious issue in global case competitions, while others do not perceive it as important.

To be able to provide students with more detailed guidelines on topics they find the most difficult task in marketing case analysis at the case competitions, it was important to explore their perceptions. The research results are presented in Table 4. 
Table 4. The Most Difficult Tasks in Marketing Case Analysis at Case Competitions

\begin{tabular}{|l|c|c|}
\hline \multicolumn{1}{|c|}{ Task } & Mean & $\begin{array}{c}\text { Std. } \\
\text { deviation }\end{array}$ \\
\hline Defining financial effects for proposed marketing strategy & 3.81 & 1.054 \\
\hline Defining sales effects for proposed marketing strategy & 3.68 & 0.891 \\
\hline $\begin{array}{l}\text { Defining possible solutions when lacking information to } \\
\text { make decision }\end{array}$ & 3.67 & 0.975 \\
\hline $\begin{array}{l}\text { Defining quantitative and qualitative criteria for } \\
\text { measuring marketing performance }\end{array}$ & 3.66 & 0.981 \\
\hline Finding data on foreign market via Internet & 3.19 & 1.141 \\
\hline Presenting action plan for proposed marketing strategy & 2.94 & 1.044 \\
\hline Target market analysis & 2.87 & 1.048 \\
\hline Industry analysis & 2.85 & 1.045 \\
\hline Competition analysis & 2.79 & 0.97 \\
\hline Company analysis & 2.6 & 0.955 \\
\hline
\end{tabular}

The most difficult tasks for the students were Defining financial effects for proposed marketing strategy $(\bar{x}=3.81)$, Defining sales effects for proposed marketing strategy $(\bar{x}=3.68)$ and Defining possible solutions when lacking information to make decision $(\bar{x}=3.67)$. Tasks that received the lowest values, hence, tasks that are not a problem to perform and analyse, are Company analysis $(\bar{x}=2.60)$, Competition analysis $(\bar{x}=2.79)$ and Industry analysis $(\bar{x}$ $=2.85$ ). When it comes to the Defining sales effects for proposed marketing strategy, standard deviation has the lowest value among the observed data. This indicates that there are no extremely low results in the data set. On the other hand, Finding data on foreign market via the Internet has a slightly larger standard deviation mean which indicates that some of the students may be facing difficulties with finding data and searching the internet, while others do not find it challenging.

All these results referring to benefits, issues and the most difficult tasks in marketing presented the respondent to the first research question - student perception about case learning process in business international case competitions.

We also investigated the selection process, which is a very important part of the preparation for case study competitions and it varies from university to university. In a research we conducted, we analysed different selection criteria. In our sample, $84.8 \%$ of the respondents stated that the selection process is performed as an extracurricular activity, while the rest of the respondents said that selection process is a part of the case course. Additional analysis of the selection process was focused on methods that are used for the selection process. Most of the respondents $(66 \%)$ said that the selection process consists of an interview, while only $12.7 \%$ of the respondents said that the selection process at their university consists of a written test. The vast majority $(92.4 \%)$ of the respondents said that they are not solving case studies individually during the selection process. Out of the 197 respondents, $86.3 \%$ do not have short team case study tests and $74.1 \%$ do not have long team case study tests. 
The grade point average is an insignificant factor in $99 \%$ of the answers. The results from local case competition are one of the selection methods in $3 \%$ of the total answers. The respondents also answered the question about whether they have a Case Study Club at their university. Out of 197 respondents, 87.8\% said that they have a case study club at their university and activities related to case competitions at their university that are managed by Case Study Club as student organizations supported with advisors team.

According to the response to the second research question we tried to provide a respondent with an insight about differences and similarities between Serbian, Australian and Thai students and other students from the sample. We compared the median value of the benefits, issues, the most difficult tasks in marketing with countries and we have tried to identify, explain and better understand the similarities and differences among Australia, Thailand and Serbia.

\section{The Benefits of Business International Case Competitions}

We analysed the similarities in terms of the benefits that students from Australia, Thailand, Serbia and other countries recognized as important to point out: gaining new knowledge, personal and professional improvement, problem solving, teamwork skills, presentation and under pressure skills, feedback 360 - consulting other team members, suggesting areas of improvement and working with mentors.

Figure 1. The Importance of Benefits of Participating in Case Competitions

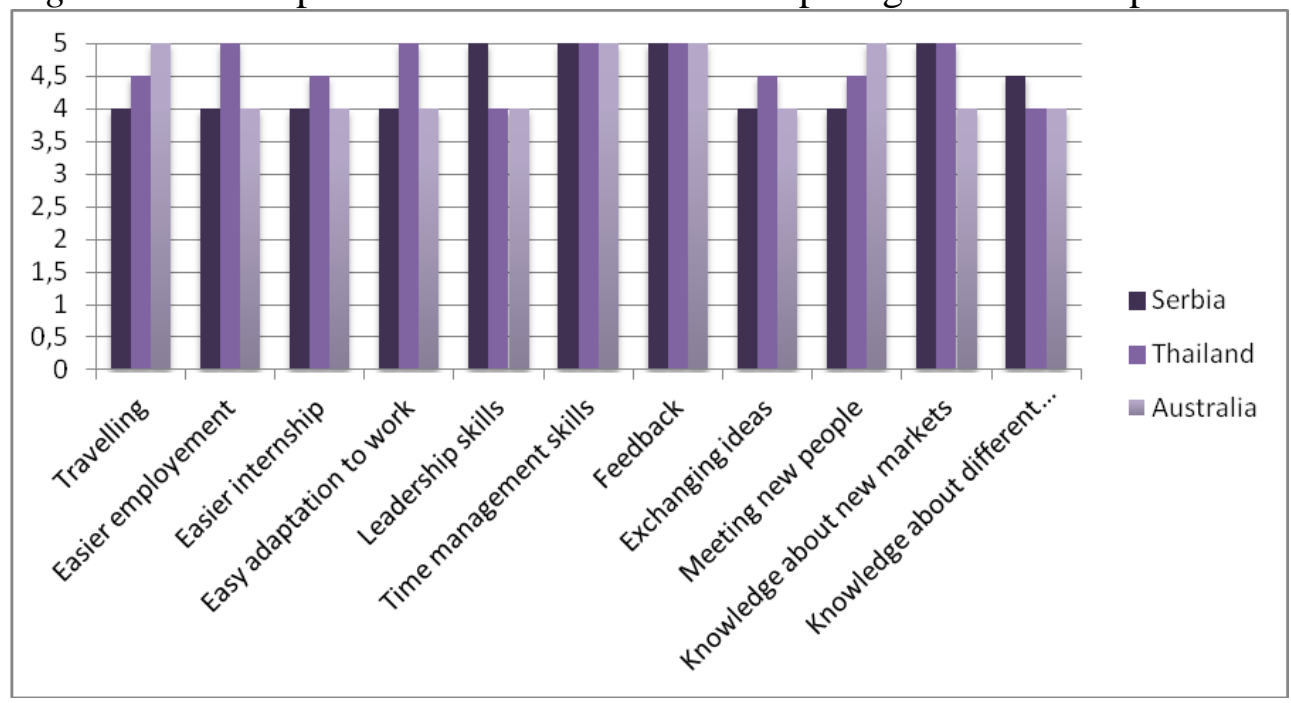

If we look at the different opinions of students when the benefits of international competitions are considered, we will see that students from Australia, Thailand and Serbia value the feedback of their mentors after case simulation as well as the development of time management skills equally. However, students from other countries put less value into these two criteria, see Figure 1. 
Meeting people from different cultures and travelling were recognized as benefits by Australian students. This points out to the need for connecting with people from all around the world and expanding their knowledge of various cultures. Thai students have a different opinion. They take importance in learning to adapt easily to work activities and having the possibility of getting a job or an internship easier. Hence, it may be concluded that case competitions definately help with employment and make candidates more attractive. Serbian students noted that out of all learning experience on case competitions, they see gaining new knowledge about different cultures and markets and development of leadership skills as the biggest advantages.

\section{The Issues of Business International Case Competitions}

Common problems for all three countries (Australia, Thailand, Serbia) and for other countries relate to: insufficient knowledge of local market, filtering the most important information while reading the case study and case study is too long - more than 30 pages.

For students from Australia the least important problems in case analysis at case competitions is that the topic of case study is not interesting, which indicates that they might be better prepared to work on a variety of topics, see Figure 2.

Figure 2.The Importance of Issues of Participating in Case Competitions

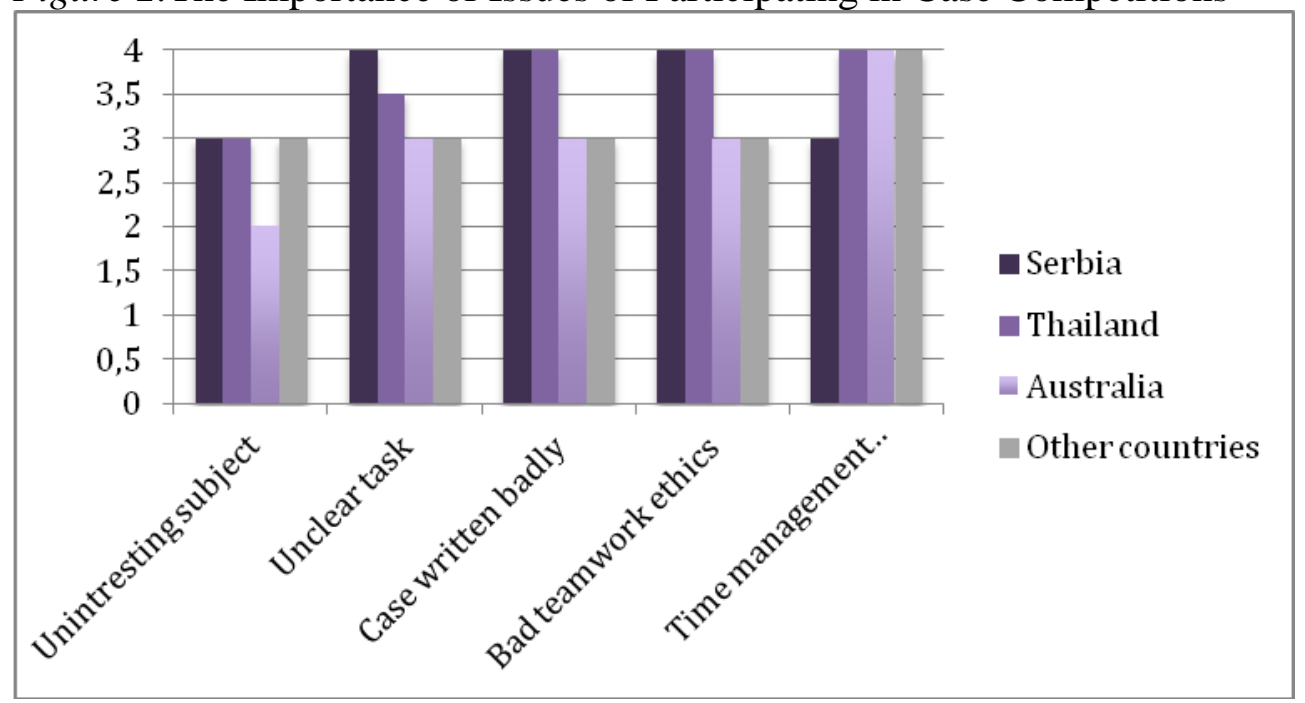

What is common for students from Thailand and Serbia is they give great importance to whether the case is poorly written and if the case study does not have well defined tasks, which is the difference in relation to Australia, and other countries included in the sample, which have a lower value.

Students from Australia, Thailand and other countries are similar because they emphasize the importance of time management, while the median value for students from Serbia is not as pronounced. Students from Serbia are also different because for them, the median value is significant in the segment of 
bad teamwork ethics, which is explained by the fact that they have a cultural need for teamwork and they consider it crucial to achieve the objectives.

\section{The Most Difficult Task in Marketing in Case Competitions}

In terms of median values for Australia, Thailand, Serbia and other countries, they all emphasize the importance of the hardest tasks in marketing, when solving case studies at international case competitions. What the most difficult task of all marketing is, refers to the definition of quantitative elements in the marketing strategy, which include sales and financial effects, as well as a combination of qualitative and quantitative criteria in measuring the results of marketing. These points might emphasize possibilities to improve practical knowledge in terms of a better understanding of the connection of knowledge from marketing to finance and sales and better connection with the company's business strategy. Also respondents from all countries emphasized that they have problems defining possible solutions when lacking some information to make a decision. It is important to teach students how to make assumptions. In this fashion, such programs as a financial model for prediction, ROI (Return on Investment) and relevant ratio, designing key performance index for greater measurement performance of business progress are strongly recommended in the case of training series.

Figure 3. Perception of the Most Difficult Marketing Task during Case Competitions

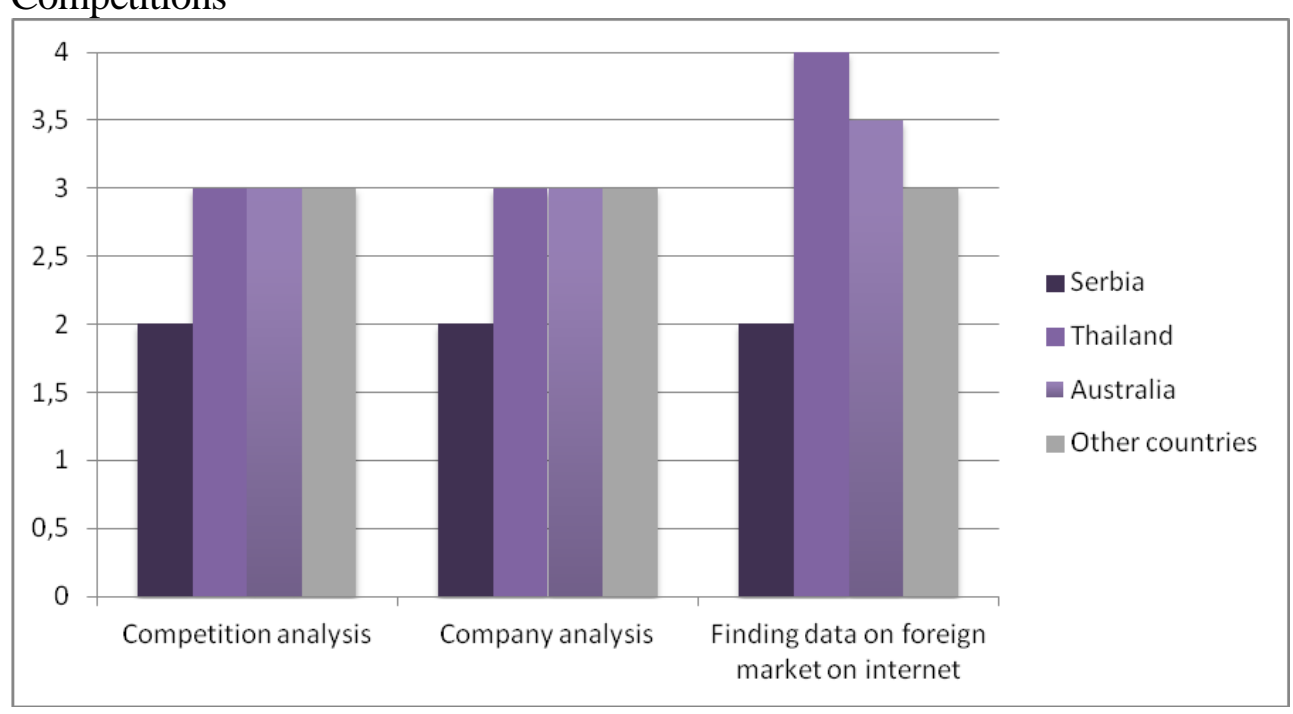

The main distinction between thinking of students from other countries is the task of finding data on foreign markets via the Internet, see Table 3. Here the similarity of students from Australia and Thailand can be seen in terms of importance of evaluating the marketing task, with the same median value 4 . Other countries were evaluated by the median value of 3 , while the median value of the same criteria in Serbia was 2, see Figure 3. This result suggests that students from Serbia might be better prepared for internet searching during 
preparation for case competitions. In addition to that, Serbian students find it easier to evaluate and complete competition and company analysis.

\section{Conclusion}

Generally, the lack of understanding the benefits of the case method as an active learning method is usually because of the limited knowledge of how to deal with a case individually and as a group (Apaydin, 2008). This paper presents the challenge and tries to answer the question: Is the business case competition a new innovative way of education for student learning? Some additional responses from respondents emphazised the high influence of case competitions on their life: "Training for and competing at a case competition was the best experience that I had at university" or "Case competitions enabled me to travel around the world, building my skills and helping me gain full time employment". "Case competitions are a great learning experience". (Karns, 2005)

Based on the results of this research, we can conclude definite benefits, issues and the most difficult tasks of case competitions from the student point of view.

First of all, the most important benefits for all of the questioned students were: improvement (personal and profesional) along with the development of managerial skills (presentation, work under pressure, problem solving and analytical skills). When comparing opinions of students Australia, Thailand and Serbia, the key similarity is the importance given to gaining new knowledge, mentor and team feedback along with teamwork skills. The most important differences are that Australians value networking and the experience gained through travel greatly, while for example Thai students appreciate the benefit of being more attractive on the job market. Possibly, this is due to a recent saturation of the Thailand job market in which each student has to build his or her portfolio for their attractiveness to the intended employers. On the other hand, leadership skills and learning about different markets and cultures is more significant for Serbian students. The key reason for that may be the lack of coverage of such topics in the standard curriculum in Serbia, throughout their formal education. Unlike students from Thailand or Australia, students in Serbia also do not have the option of living and studying abroad as often.

When talking about issues faced during case competitions, students mostly adress: time constraints and time management, insufficient knowledge of local market, filtering the most important information while reading the case study and setting priorities. Once again, some similarities can be found considering the perception of Australian and Thai students, who give great importance to time management and issues with constraints. On the other hand, Serbian students found that bad teamwork ethics can be one of the key challenges during case solving. In addition, Serbian and Thai students take more notice of how the case study is written and what the tasks are. They are also more prepared to solve the case study even if the topic is unappealing, which is not 
something Australians have noted.

Thirdly, when considering the most difficult tasks from the field of marketing during the case study, all students pointed out that measuring quantitative financial and sales results is definately the biggest challenge. Similar conclusions have been driven in previous research of opinions of students from Serbia and Croatia (Corner, et al., 2006). A possible reason for this may be that students lack the common connection between the subjects they are taking as a part of the curriculum: marketing, finance and sales. Furthermore, students find the lack of information to be a problem when it comes to strategic decision making and formulating long term marketing strategies. That is why it is neccessary to stimulate students to overcome lack of knowledge when it comes to assumptions and educated guessing through solving case studies (exampling leading consuting houses such as McKinsey, BCG, PwC, KPMG, EY, Bain) (Ammerman, 2012). Analysis is also a part of the problem for some, students from Australia and Thailand, noted that finding additional information on the internet is an issue. These students, as representatives of generation $\mathrm{Y}$ do not go through adequate training for efficient internet search. However, students from Serbia have not stated that issue, due to the fact that they recieve relevant training prior to the case competitions.

This research study has some limitations as well. The first constraint is that the results have not considered the different experiences students may have had in their case competitions, which may affect their replies. Also, another limitation is the fact that this study only represents the students' point of view. Future research studies will include the opinion of mentors as well, providing a clearer image of this relatively new innovative learning method through case study competitions.

Some additional comments also suggested building a unique common platform for all case competitions. The purpose of this platfrom is to create a network of case competitors, therby remaining in contact, sharing experiences and information about possible business opportunities and most importantly including a diverse mix of universities and countries (such as India) which will maximise the benefits for both students and teachers.

\section{References}

Ammerman, P. (2012). Applying the case study approach in a corporate context. In P. Ammerman, A. Gaweł, M. Pietrzykowski, R. Rauktienè, \& T. Williamson (Eds), The Case Study Method in Business Education, Transfer of experiential and innovative teaching method for business education (pp. 95-104). Poznań: Bogucki Wydawnictwo Naukowe.

Apaydin, M. (2008). Making a case for the case method in Turkey, Journal of Management Development, 27(7), 678-692.

Australian Undergraduate Business Case Competition (AUBCC) (n.d.). Retrieved from http://bit.ly/2nRorkb.

Bale, J.M., Senteza, J., \& White, T.A, (2013). A model for running an undergraduate business-focused case competition, international research. Journal of Applied Finance, 1-16. Retrieved from http://bit.ly/2mPvCrm. 
Belgrade Business International Case Competition (BBICC) (n.d.). Retrieved from http://bit.ly/2n72IoC.

Burke, L.A., \& Rau, B. (2010). The research-teaching gap in management. Academy of Management Learning and Education, 9(1): 132-143.

Burke, M.G, Carter, J.D, \& Hughey, W.A, (2013). The use of case study competitions to prepare students for the world of work. Industry \& Higher Education, 27(3), $157-162$.

Byrne, J.A. (2012, November 11). How the world's top business schools teach their MBA's. Poets \& Quants. Retrieved from http://bit.ly/2o7AwkN.

Corner, P.D., Bowden, S., Clark, D., Collins, E., Gibb, J., Kearins, K., \& Pavlovich, K. (2006). Grounded learning from a strategy case competition. Journal of Management Education, 30, 431-454.

Credle, S.H. (2007). The development of the case based learning and assessment objective: the case of prudential insurance company's optimal entry strategy to China. Presentation, to the North America Case Writers Association. Keystone, Colorado.

Damnjanovic, V., \& Dlačić, J., (2015). Perceived students' benefits of case study learning in marketing: comparative analysis of Croatia and Serbia. $24^{\text {th }}$ CROMAR Congress, Proceedings Marketing Theory And Practice- Building Bridges And Fostering, 252-268. Collaboration, Split, ISBN: 978-953-281-067-7.

Dlačić, J., Damnjanović, V., \& Ribarić, I. (2017, forthcoming). Improving learning through case study competitions: Challenges for teachers and students. Ekonomski vjesnik/Econviews- Review of Contemporary Business, Entrepreneurship and Economic Issues.

Erskine, J.A., Leenders, M.R., \& Mauffette-Leenders, L.A. (1998). Teaching with cases (3rd ed.). London, ONT: Ivey Publishing, Ivey School of Business Administration. The University of Western Ontario.

Gamble, E.N., \& Jelley, R.B. (2014). The case for competition: learning about evidence-based management through case competition. Academy of Management Learning \& Education, 13(3), 433-445.

Greenhalgh, A.M. (2007). Case method teaching as science and art: a metaphoric approach and curricular application. Journal of Management Education, 3(2), 181-194.

Jerrard, M.A. (2005). Assessing student learning and skills using the case study method. Journal of New Business Ideas and Trends, 3(1), 27-36.

Karns, G.L. (2005). An update of marketing student perceptions of learning activities: structure, preferences, and effectiveness. Journal of Marketing Education, 27(2), $163-171$.

Kreber, C. (2001). Learning experimentally through case studies? A conceptual analysis. Teaching in Higher Education, 6(2), 217-228.

Menna, A., (2010). The business case method: an examination of a 2009 case competition. Management in Education, 24(2), 74- 79.

Mondéjar-Jiménez, J.A., Cordente-Rodríguez, M., Gómez-Borja, M.A., AndrésMartíne, M.E., \& Gázquez-Abad, J.C. (2010). Case studies as practical teaching in the new marketing courses. American Journal of Business Education-Special Edition, 3(13), 33-38. Retrieved from http://bit.ly/2msg7KZ.

Orlitzky, M., \& Benjamin, J.D. (2003). The effects of sex composition on small-group performance in a business school: A case competition. Academy of Management Learning and Education, 2, 128-138.

Sachau, D.A., \& Nass, P. (2010). The consulting challenge: A case competition. Journal of Management Education 34(4), 605-631. 
Thammasat Undergraduate Business Challenge (TUBC). (n.d.). What is TUBC? Retrieved from http://bit.ly/2nBojZ4.

Umble, E.J., Umble, M., \& Artz, K. 2008. Enhancing undergraduates' capabilities through team-based competitions: The Edward Jones challenge. Decision Sciences Journal of Innovative Education, 6(1), 1-27.

University of Auckland. Undergraduate international case competition list. Retrieved from http://bit.ly/2nLssdm. 
Appendix 1. The List of 22 International Undergraduate Business Case Competitions

\begin{tabular}{|c|c|c|c|c|c|}
\hline Number & Date & Competition & Venue & Country & $\begin{array}{l}\text { Number } \\
\text { of Teams }\end{array}$ \\
\hline 1. & Feb 2016 & $\begin{array}{l}\text { Champions Trophy Case } \\
\text { Competition }\end{array}$ & $\begin{array}{l}\text { University of } \\
\text { Auckland }\end{array}$ & $\begin{array}{l}\text { New } \\
\text { Zealand }\end{array}$ & 12 \\
\hline 2. & Feb 2016 & $\begin{array}{l}\text { BI International Case } \\
\text { Competition }\end{array}$ & $\begin{array}{l}\text { BI Norwegian } \\
\text { Business School }\end{array}$ & Norway & 12 \\
\hline 3. & Feb 2016 & $\begin{array}{l}\text { Heavener International Case } \\
\text { Competition }\end{array}$ & $\begin{array}{l}\text { University of } \\
\text { Florida }\end{array}$ & USA & 20 \\
\hline 4. & Feb 2016 & $\begin{array}{l}\text { John Molson Undergraduate } \\
\text { Case Competition }\end{array}$ & $\begin{array}{l}\text { Concordia } \\
\text { University }\end{array}$ & Canada & 24 \\
\hline 5. & Feb 2016 & CBS Case Competition & $\begin{array}{l}\text { Copenhagen } \\
\text { Business School }\end{array}$ & Denmark & 12 \\
\hline 6. & $\begin{array}{l}\text { Mar } \\
2016 \\
\end{array}$ & $\begin{array}{l}\text { McGill Management } \\
\text { International Case Competition }\end{array}$ & McGill University & Canada & 12 \\
\hline 7. & $\begin{array}{l}\text { Mar } \\
2016\end{array}$ & $\begin{array}{l}\text { Sauder Summit Global Case } \\
\text { Competition }\end{array}$ & $\begin{array}{l}\text { UBC Sauder } \\
\text { School of } \\
\text { Business }\end{array}$ & Canada & 12 \\
\hline 8. & $\begin{array}{l}\text { Mar } \\
2016 \\
\end{array}$ & $\begin{array}{l}\text { Scotiabank International Case } \\
\text { Competition }\end{array}$ & $\begin{array}{l}\text { Ivey Business } \\
\text { School }\end{array}$ & Canada & 12 \\
\hline 9. & $\begin{array}{l}\text { Mar } \\
2016 \\
\end{array}$ & $\begin{array}{l}\text { University of Navarra } \\
\text { International Case Competition }\end{array}$ & $\begin{array}{l}\text { University of } \\
\text { Navarra }\end{array}$ & Spain & 16 \\
\hline 10. & $\begin{array}{l}\text { Apr } \\
2016 \\
\end{array}$ & $\begin{array}{l}\text { International Case } \\
\text { Competition@Maastricht }\end{array}$ & $\begin{array}{l}\text { Maastricht } \\
\text { University }\end{array}$ & Netherland & 16 \\
\hline 11. & $\begin{array}{l}\text { Apr } \\
2016 \\
\end{array}$ & $\begin{array}{l}\text { The Global Business Case } \\
\text { Competition }\end{array}$ & $\begin{array}{l}\text { University of } \\
\text { Washington }\end{array}$ & USA & 12 \\
\hline 12. & $\begin{array}{l}\text { Apr } \\
2016 \\
\end{array}$ & $\begin{array}{l}\text { Belgrade Business International } \\
\text { Case Competition }\end{array}$ & $\begin{array}{l}\text { University of } \\
\text { Belgrade }\end{array}$ & Serbia & 16 \\
\hline 13. & $\begin{array}{l}\text { May } \\
2016\end{array}$ & $\begin{array}{l}\text { Chulalongkorn International } \\
\text { Business Case Competition }\end{array}$ & $\begin{array}{l}\text { Chulalongkorn } \\
\text { University }\end{array}$ & Thailand & 12 \\
\hline 14. & Jun 2016 & $\begin{array}{l}\text { HSBC/HKU Asia Pacific } \\
\text { Business Case Competition } \\
2016\end{array}$ & $\begin{array}{l}\text { Hong Kong } \\
\text { University }\end{array}$ & $\begin{array}{l}\text { Hong } \\
\text { Kong }\end{array}$ & 30 \\
\hline 15. & $\begin{array}{l}\text { Aug } \\
2016\end{array}$ & $\begin{array}{l}\text { SDS Queenstown International } \\
\text { Case Competition }\end{array}$ & $\begin{array}{l}\text { University of } \\
\text { Otago }\end{array}$ & $\begin{array}{l}\text { New } \\
\text { Zealand }\end{array}$ & 12 \\
\hline 16. & $\begin{array}{l}\text { Aug } \\
2016 \\
\end{array}$ & $\begin{array}{l}\text { Asian Business Case } \\
\text { Competition }\end{array}$ & $\begin{array}{l}\text { Nanyang Business } \\
\text { School }\end{array}$ & Singapore & 9 \\
\hline 17. & $\begin{array}{l}\text { Sep } \\
2016\end{array}$ & UOB-NUS Case Competition & $\begin{array}{l}\text { National } \\
\text { University of } \\
\text { Singapore } \\
\end{array}$ & Singapore & 16 \\
\hline 18. & Oct 2016 & $\begin{array}{l}\text { Thammasat Undergraduate } \\
\text { Business Challenge }\end{array}$ & $\begin{array}{l}\text { Thammasat } \\
\text { University }\end{array}$ & Thailand & 16 \\
\hline 19. & Oct 2016 & $\begin{array}{l}\text { Citi- HKUST International Case } \\
\text { Competition }\end{array}$ & $\begin{array}{l}\text { Hong Kong } \\
\text { University of } \\
\text { Science and } \\
\text { Technology }\end{array}$ & $\begin{array}{l}\text { Hong } \\
\text { Kong }\end{array}$ & 18 \\
\hline 20. & Oct 2016 & Global Business Case Challenge & $\begin{array}{l}\text { Ritsumeikan Asia } \\
\text { Pacific University }\end{array}$ & Japan & 13 \\
\hline 21. & $\begin{array}{l}\text { Nov } \\
2016\end{array}$ & $\begin{array}{l}\text { FEP-U.Porto International Case } \\
\text { Competition }\end{array}$ & Porto University & Portugal & 12 \\
\hline 22. & $\begin{array}{l}\text { Nov } \\
2016\end{array}$ & $\begin{array}{l}\text { Australian Undergraduate } \\
\text { Business Case Competition }\end{array}$ & $\begin{array}{l}\text { University of } \\
\text { Melbourne }\end{array}$ & Australia & 16 \\
\hline
\end{tabular}

Source: Auckland, 2017, Modified by authors. 
